\title{
Examination of the Crime of Genocide Under the Rome Statute of the International Criminal Court
}

\author{
Dr. Ibe Okegbe Ifeakandu ${ }^{1}$ \\ Nigerian Institute of Advanced Legal Studies, \\ Supreme Court Complex, Three Arms Zone, Central Business District, Abuja \\ Dr. Charles Emeka Ochem \\ Faculty of Law, Igbinedion University, Okada, Edo State, Nigeria
}

\begin{abstract}
.
The crime of genocide has historical antecedents, dating back to several decades before its eventual acceptance as an international crime and codified as such. Ironically, the Convention on the Prevention and Punishment of the Crime of Genocide, 1948 (the Genocide Convention) did not provide punishment for the crime of genocide or genocide related matters. Instead, it empowered the Contracting Parties to undertake to enact, in accordance with their respective Constitutions, the necessary legislation to give effect to the provisions of the Convention and, in particular, to provide effective penalties for persons guilty of genocide. But this lacuna is covered in Part 7 of Article 77 of the Rome Statute of the International Criminal Court (ICC Statute), which provides applicable penalties for a person convicted of genocide or genocide related matters. Generally, conducts that amount to genocide are clear even though definition of the four classes of group 'is an intricate problem that requires serious interpretative efforts'. This paper examines the crime of genocide under the Statute of the International Criminal Court. The paper begins by examining the general overview of the crime of genocide by way of introduction and historical background; and then proceeds to appraise the very nature of the crime and the requirement of proving the offence. Noting the difficulties associated with proving the crime of genocide, particularly 'intent', the paper examines situations wherein inference can be drawn. The paper concludes with overarching recommendations.
\end{abstract} Keywords: Genocide, Genocide Convention, intent, dolus specialis, jus cogens, ICC.

DOI: $10.7176 / \mathrm{JLPG} / 105-05$

Publication date: January $31^{\text {st }} 2021$

\section{Introduction}

The definition of Genocide in the Genocide Convention has been incorporated into the various statutes namely: (a) the Rome Statute, (b) the Statute of the International Criminal Tribunal for the Former Yugoslavia (ICTYSt), (c) the International Criminal Tribunal for Rwanda Statute (ICTRSt) as well as other court's instruments established by or with the support of the UN. ${ }^{2}$ The Genocide Convention defines genocide in Article 2 as:

'... any of the following acts committed with intent to destroy, in whole or in part, a national, ethnical, racial or religious group, as such':

(a) Killing members of the group;

(b) Causing serious bodily or mental harm to members of the group;

(c) Deliberately inflicting on the group conditions of life calculated to bring about its physical destruction in whole or in part;

(d) Imposing measures intended to prevent births within the group;

(e) Forcibly transferring children of the group to another group.

Genocide is an indiscriminate killing of a group of people with total disregard for the individual's life. Its immediate effect is death and, dehumanization. For example, it is estimated that more than two hundred thousand people were killed in Darfur, Sudan during the genocide and over two million persons were internally displaced. ${ }^{3}$ Genocide has global impact. It disregards international law, creates political instability, destroys entire cultures, and obliterates morals. Kenneth J. Campbell in his book "Genocide and the Global Village" indicates that unchecked genocide will eradicate global cooperation and make larger conflicts inevitable If genocide goes

\footnotetext{
${ }^{1}$ * Associate Professor and Deputy Head of Postgraduate School. Nigerian Institute of Advanced Legal Studies; B.A (Hons), LLB (Hons), MPA (O.A.U, Ile-Ife), B. L (Abuja), LLM (Nasarawa), Ph. D. (University of Wales, Aberystwyth, United Kingdom);

* Associate Professor and Sub-Dean, School of Postgraduate Studies and Research, Igbinedion University, Okada, Edo State; LLB (Hons), LLM (O. A. U, Ile-Ife), Ph.D. (Igbinedion University, Okada, Edo State);

${ }^{2}$ Diane F Orentlicher, (1999) 'Genocide' in Roy Gutman, David Rieff and Anthony Dworkin (ed) Crimes of War: What the Public Should Know 2.0 (Reprint - edition W W Norton \& Co 191.

3 "Civilian Devastation: Abuses by all Parties in the War in Southern Sudan “, (1994), Human Rights, Watch. www.hrw.org/hrw/pubweb/webcat-93.htm. Accessed on 26/11/2020.
} 
unchecked, no group is save as every group could be the next target Campbell further said that even the most powerful nations may be drawn in and ultimately it may threaten civilization through accidental or international use of more powerful weapons. Genocide when compared with war crimes and crimes against humanity, is generally regarded as the most heinous crime. At worst, genocide pits neighbour against neighbour, or even husband against wife. Unlike war, where the attack is general and the object is after the control of a geographical or political region, genocide attack individual's identity. The object is complete elimination of a group of people.

Genocidal actions have, over the years, become wide spread; and although the word was coined in response to the Armenian and holocaust killings, it now applies to other mass killings such as the Kurdish genocide in Iraq, ${ }^{1}$ the Bosnian genocide, ${ }^{2}$ and the Rwandan genocide, ${ }^{3}$ amongst others. Importantly, developments in this area have led to genocide being recognised as a norm of international custom. ${ }^{4}$ The International Court of Justice (ICJ) ${ }^{5}$ attested to this fact when it stated: "the principles expressed in the Genocide Convention are part of general customary international law". 6 Therefore, all states are under obligation to respect the principles whether or not they ratify the Convention. ${ }^{7}$ This effectively imposes a responsibility on states to recognise genocide as a peremptory norm of international law (jus cogens) to which no derogation is allowed. ${ }^{8}$ The purpose of this paper is to examine the concept of Genocide as international criminal conduct set out in the Rome Statute of the International Criminal Court (ICC Statute). With specific reference to the nature of the crime, the paper highlights the crime as one that embodies the principle of special intent (dolus specialis) as well as the specific elements of the crime in relation to what is required to effectively establish that the crime of genocide has been committed.

\section{Historical Perspective}

Genocide is historically linked to a Polish lawyer called Raphael Lemkin, ${ }^{9}$ who coined the word from the Greek and Latin prefixes-genos (race/tribe) and cide (killing). The word was devised (a) in reaction to the Nazi policies of systematic murder of Jewish people during the holocaust; and (b) in response to previous instances in history of targeted actions aimed at destroying particular groups of people. ${ }^{10}$ Events of that period led Lemkin to steer a vigorous campaign to actualise international recognition and codification of genocide as an international crime. ${ }^{11}$ Genocide was eventually recognised as a crime under international law in 1946 by a resolution of the United Nations General Assembly (GA); ${ }^{12}$ and later codified as an independent crime under the Convention on the Prevention and Punishment of the Crime of Genocide, 1948 (the Genocide Convention). ${ }^{13}$

The need to recognise and codify genocide as international crime arises from the immense loss often associated with the conduct. This is expressed in a number of documents such as (a) the preamble to the Genocide Convention to the effect that "... at all periods of history genocide has inflicted great losses on humanity..."14 (b) the travaux préparatoires of the Convention which refers to genocide as an historical fact; ${ }^{15}$ and (c) a GA resolution ${ }^{16}$ that refer to many instances of crimes of genocide that occurred when "racial, religious, and other groups have been destroyed, entirely, or in part." 17 This essentially reaffirms (i) the notion that genocide is not a new phenomenon; and (ii) that events that occurred before the adoption of the Genocide Convention have the

\footnotetext{
${ }^{1}$ This genocide took place between 1986-1989. It targeted the Kurds. Consequently, between 500, 000 and 182,000 Kurds were killed. See Human Rights Watch, Genocide in Iraq, at <www.humanrightswatch.org > accessed 1 May 2018

${ }^{2}$ The Bosnian genocide usually refers either to the genocide committed by the Bosnian Serb forces in 1995 or the wider ethnic cleansing campaign throughout areas controlled by the Army that took place during the 1992-1995 Bosnian War. See John Richard Thackrah, (2008): The Routledge Companion to Military Conflict since 1945 Routledge Companion Series, Taylor \& Francis), 81-84

${ }^{3}$ This was the genocidal mass slaughter of the Tutsis in Rwanda where an estimated 500,000-1,000,000 Rwandans were killed during a 100day period from 7 April to mid-July 1994. See BBC, Rwanda: How the Genocide Happened, 17 May 2011, <www.bbc.com> accessed 2 July 2018

${ }^{4}$ A norm of international custom (jus cogens) is a peremptory norm that cannot be derogated from. See Lawrence R. Helfer and Ingrid B. Wuerth, (2016) "Customary International Law: An Instrument Choice Perspective" Michigan Journal of International Law, 37 (4), 563

${ }^{5}$ The ICJ was set up in 1945 under the UN Charter to be the principal organ of the organization and its basic instrument (Statute of the ICJ) forms part of the Charter-Chapter XIV. It began work in 1946. See ICJ at <www.icj-cij.org > 7 June 2018

${ }^{6}$ See ICJ, Application of the Convention on the Prevention and Punishment of the Crime of Genocide (Bosnia and Herzegovina v Serbia and Montenegro) Judgement, I.C.J Reports, 2007, pp 39-44

${ }^{7}$ Ibid

${ }^{8}$ See International Law Commission at $<$ http://legal.un.org/ilc/summaries/1 14.shtml $>7$ June 2020

${ }^{9}$ Raphael Lemkin, (1944).Axis Rule in Occupied Europe: Laws of Occupation, Analysis of Government, Proposals for Redress (Washington, Carnegie Endowment for International Peace, Division of International Law,

${ }^{10}$ Ibid.

${ }^{11}$ According to the British Broadcasting Corporation (BBC), Lemkin began to campaign for genocide to be recognised as a crime under international after witnessing the horrors of the holocaust that claimed the lives of his entir.e family except his brother. See BBC, How do you define genocide? < www.bbc.com $>7$ June 2020

${ }^{12}$ See resolution A/RES/96-1.

${ }^{13}$ The Convention was adopted in 1948 but it came into force on 12 January 1951 , the $19^{\text {th }}$ day following the date of deposit of the twentieth instrument of ratification or accession, in accordance with article XIII has been ratified by 149 States as at January 2018.

${ }^{14}$ Ibid.

${ }^{15}$ See Brill Online. The Genocide Convention: The Travaux Preparatoires (2 vols.) (2009), <http://brill.com> accessed 6 August 2018 .

${ }^{16}$ Resolution 96(I) (11 December 1946) of the United Nations General Assembly.

${ }^{17}$ Ibid.
} 
characteristics of genocide as defined in the Convention.

\section{Definition of Genocide}

The word genocide was first defined in article II of the Genocide Convention as:

Any of the following acts committed with intent to destroy, in whole or in part, a national, ethnical, racial or religious group, as such:

a Killing members of the group;

b Causing serious bodily or mental harm to members of the group;

c Deliberately inflicting on the group conditions of life calculated to bring about its physical

destruction in whole or in part;

d Imposing measures intended to prevent births within the group;

e Forcibly transferring children of the group to another group.

With regard to this definition, the important point to note is that it came as an outcome of high-powered negotiating process that reflects the compromise reached among UN Member states in $1948^{1}$ during the critical time of drafting the Convention. This possibly accounts for why the definition is adopted verbatim in article 6 of the Statute of the International Criminal Court (ICC Statute) ${ }^{2}$ and in some other Statutes of international and hybrid jurisdictions such as the Statute of the International Criminal Tribunal for Former Yugoslavia (ICTY) ${ }^{3}$ and International Criminal Tribunal for Rwanda (ICTR). ${ }^{4}$

Following the adoption of genocide as part of peremptory norm of international law, states began to criminalise it in their domestic law while many are yet to do so. An example of a state that has criminalised genocide is Ethiopia where the High Court tried and convicted former President Mengistu in absentia in Mengistu $\&$ ors ${ }^{5}$ on charges of genocide. ${ }^{6}$ However, several states are yet to specifically criminalise genocide in their national laws.

\section{Genocide under the ICC Statute}

The crime of genocide is one of the four omnibus crimes within the jurisdiction of the $\mathrm{ICC}^{7}$ as contained in article 5 of the ICC Statute. As already noted and for purposes of emphasis, the critical need to create a special criminal court to try people for atrocities committed during armed conflict had been contemplated by the United Nations (UN) at different times after the Second World War (WW II) culminating in the setting up of two ad hoc tribunals in 1993 and 1994. This is for purposes of giving effect to the crime through the punishment of serious violations of international humanitarian law committed, respectively, in the former Yugoslavia and Rwanda. A series of negotiations to establish a permanent international criminal court that would have jurisdiction over serious international crimes regardless of where they were committed started up in 1994 and led to the adoption of the ICC Statute in July 1998 in Rome.

This accomplishment is the culmination of years of effort and shows the resolve of the international community to ensure that those who commit grave crimes do not go unpunished. Genocidal actions were treated as a sub class of crimes against humanity until after the adoption of Genocide Convention in 1948 when it became crime per se. Genocide as a crime of individuals began to be punished following the establishment of the International Criminal Tribunal for Former Yugoslavia (ICTY) ${ }^{8}$ and International Criminal Tribunal for Rwanda $(\text { ICTR })^{9}$ both of which provide for the crime of genocide.

\footnotetext{
${ }^{1}$ See the United Nations Office on Genocide Prevention and the Responsibility to Protect www.un.org/preventgenocide/adviser

2 The Rome Statute of International Criminal Court is the treaty, which established the International Criminal Court's jurisdiction, structure and functions. It was adopted on July 17, 1998 and entered into force on July 1, 2002 as the $60^{\text {th }}$ instrument of ratification was deposited with the Secretary General on April 11, 2002 when 10 countries simultaneously deposited their instruments of ratification. See also, http://www.un.org/law/icc/statute/romefra.htm: accessed 12 September 2020.

${ }^{3}$ The International Criminal Tribunal for Former Yugoslavia (ICTY) is a UN Tribunal with jurisdiction to try war crimes committed during the conflicts in the Balkans in the 1990s. It was established in 1993. More information about the Tribunal can be obtained at, http://www.icty.org/sections/AbouttheICTY; accessed 20 November 2020.

${ }^{4}$ The International Tribunal for Rwanda was established by the UN Security Council by resolution 955 of November 8 , 1994 following wide spread violations of humanitarian law in Rwanda. The Tribunal was established to prosecute persons responsible for genocide and other serious crimes in Rwanda between January 1 and December 31, 1994. More information on the establishment, powers and functions of the Tribunal are available at, http://www.unictr.org; accessed 6 December 2020. See also Article 5, Statute of International Criminal Tribunal for Former Yugoslavia; U. N. Doc. S/25/04 at 36, and S/25704/Add.1 (1993); adopted by Security Council on May 25, 1993, U.N.Doc S/RES/827 (1993). ${ }^{5}$ See generally, Firew Kebede Tiba, (2007) “The Mengistu Genocide Trial in Ethoipia” Journal of International Criminal Justice 2(1), 513528.

${ }^{6}$ Ibid.

${ }^{7}$ Article 1 of ICC Statute established the ICC to try crimes listed in article 5, i.e. genocide, crimes against humanity, war crimes and very recently, crime of aggression.

${ }^{8}$ The International Criminal Tribunal for Former Yugoslavia (ICTY) is a UN Tribunal with jurisdiction to try war crimes committed during the conflicts in the Balkans in the 1990s. It was established in 1993. More information about the Tribunal can be obtained at, http://www.icty.org/sections/AbouttheICTY; accessed 17 November 2020.

${ }^{9}$ The International Tribunal for Rwanda was established by the UN Security Council by resolution 955 of November 8,1994 following wide spread violations of humanitarian law in Rwanda. The Tribunal was established to prosecute persons responsible for genocide and other serious
} 


\subsection{Elements of the Crime of Genocide}

The important point to note from the outset is the importance of article I of the Genocide Convention in terms of its content to wit: (a) that genocide could occur in the context of armed conflicts of international or noninternational nature, (b) it could also occur in peace times-this situation is not common even though it remains a possibility, (c) obligation of contracting parties to prevent and punish the crime of genocide. Authors, commentators and experts ${ }^{1}$ are however of the opinion that the definition of genocide under article II of the Genocide Convention is narrow, containing mainly two elements-mental (subjective) and physical (objective); and that what constitutes genocide tends to be broader than the content of the norm under international law. In general terms, elements of the crime of genocide are discussed in this paper under two heads-objective elements and subjective elements.

\subsubsection{Objective/physical element}

As noted above, conducts that may constitute genocide are clearly labelled in Article II of the Genocide Convention namely:

a Killing members of a particular group referred to as a 'protected group' who may be of the same national, ethnic, racial or religious links. ${ }^{2}$

b Causing serious bodily or mental harm of a 'protected group'

c Deliberately inflicting on the group conditions of life calculated to bring about its physical destruction in whole or in part

$\mathrm{d} \quad$ Imposing measures intended to prevent birth within the group; or

e Forcibly transferring children of the group to another group

For experts, conducts that amount to genocide are clear even though definition of the four classes of group 'is an intricate problem that requires serious interpretative efforts' ${ }^{3}$ These conducts were clearly spelt out in a number of judgements of the ICTR, including the judgement in Akayesu case. ${ }^{4}$ Judicial pronouncements on the acts constituting genocide are highlighted as follows:

a With regards of killing members of a group, 'killing' must be interpreted as 'murder' -voluntary or international killing

b In terms of causing serious bodily or mental harm, the ICTR held in Akayesu that the harm caused 'do not necessarily mean that the harm is permanent or irremediable'. It is enough if it involves harm that goes beyond temporary unhappiness, embarrassment or humiliation. Further, the harm must be such that results in grave and long term disadvantage to a person's ability to lead a normal and constructive life. The ICTY TC relied on this pronouncement and stated clearly in Krstic ${ }^{5}$ that inhuman treatment; torture, rape, sexual abuse and deportation are among the acts that may cause serious bodily or mental harm. The ICT further include sexual violence, mental torture and persecution in Prosecutor v Blagojevic and Jokic ${ }^{6}$ and Prosecutor v. Georges Nderubumwe Rutaganda. ${ }^{7}$

c On the issue of deliberately inflicting on the group conditions of life calculated to bring about its physical destruction, the TC held in Akayesu that 'subjecting a group of people to a subsistence diet, systematic expulsion from homes and the reduction of essential medical services below minimum requirement(s), or the deliberate deprivation of resources indispensable for survival, such as food or medical services. The list also extends to the "creation of circumstances that would lead to a slow death, such as lack of proper housing, clothing and hygiene or excessive work or physical exertion' ${ }^{8}$

d The ICTR in Akayesu also held that 'imposing measures intended to prevent birth within the group' includes 'sexual mutilation, the practice of sterilization, forced birth control and the separation of the sexes and the probation of marriages'. More crucially, the measures may be physical or mental and include 'rape as an act directed to prevent births when the woman is raped refuses subsequently to procreate.'

e With regards to forcibly transferring of children to another group, Article 6 (e) clearly specify elements

crimes in Rwanda between January 1 and December 31, 1994. More information on the establishment, powers and functions of the Tribunal are available at, http://www.unictr.org; accessed 17 November 2020.

${ }^{1}$ See Kok-Thay Eng, Redefining Genocide, at <www.genocidewatch.org> accessed 17 November 2020.. See also, Carola Lingaas, (2015)

"The Elephant in the Room: The Uneasy Task of Defining 'Racial' in International Criminal Law" 3 International Criminal Law Review

${ }^{2}$ Antonio Cassesse, (2008) International Criminal Law (2 ${ }^{\text {nd }}$ edn.: Oxford University Press) p.133

${ }^{3}$ Ibid

${ }^{4}$ Prosecutor v Akayesu, Judgement No: ICTR-96-4-T (September 2, 1998)

${ }^{5}$ Radislav Krstic was indicted for war crimes by the ICTY in connection with genocide of around 8, 000 Bosniak and civilians on 11 July 1995 during the Srebrenica massacre (outcome of Bosnia-Serbia war), known to be Europe's worst atrocity since WWII. On 2 August 2001 , Krstic became the first man to be convicted of genocide by the ICTY and sentenced to 46 years in prison

${ }^{6}$ Case No. IT-02-60-T (Prosecutor v. Blagojevic and Jokic (Judgement on Motions for Acquittal pursuant to Rule 98 Bis) International Criminal Tribunal for the former Yugoslavia, 5 April 2004 www.refworld.org/cases.ICTY.47fdfb302.htm/ accessed 17 November 2020.

${ }^{7}$ Case No. ICTR-96-3-T < www.refworld.org/cases.ICTR.415923304.html accessed 17 November 2020.

${ }^{8}$ See also Cassesse, note 28 at $133-134$

${ }^{9}$ Ibid. Akayesu, note 30 at para, 507-8. 
of the crime of genocide as follows:

- The perpetrator forcibly transferred one or more persons

- Such person or persons belonged to a particular national, ethnical, racial or religious group

- The perpetrator intended to destroy, in whole or in part, that national, ethnical, racial or religious group, as such.

- The transfer was from that group to another group.

- The person or persons were under the age of 18 years. Note that persons under the age of 18 are regarded as children as contained in international law instruments including the (CRC). ${ }^{1}$

- The perpetrator knew, or should have known, that the person or persons were under the age of 18 years.

- The conduct took place in the context of a manifest pattern of similar conduct directed against that group or was conduct that could itself effect such destruction.

By and large, forcibly transferring children of the group to another group may constitute threats, intimidation leading to the forcible transfer of children to another group. ${ }^{2}$

\subsubsection{Subjective/mental element}

Article 9 of the ICC Statute stipulates that elements of Crimes shall assist the Court in the "interpretation and application of articles 6, 7 and 8 consistent with the Statute". Regarding these elements, the provisions of the Statute, including article 21 as well as the general principles set out in Part 3 are applicable. Article 30 specifies that a person shall be criminally responsible and liable for punishment for a crime within the jurisdiction of the Court only if the material elements are committed with intent and knowledge. Where no reference is made in the Elements of Crimes to a mental element for any particular conduct, consequence or circumstance listed, it is understood that the relevant mental element, i.e., intent, knowledge or both, set out in article 30 applies. Exceptions to the article 30 standard, based on the Statute, (including applicable law under its relevant provisions), are indicated as:

1. Existence of intent and knowledge can be inferred from relevant facts and circumstances.

2. In cases relating to mental elements associated with elements involving value judgment, such as those using the terms "inhumane" or "severe", it is not necessary that the perpetrator personally completed a particular value judgment, unless otherwise indicated.

The mental element is contained in Article II (1) of the Genocide Convention, Articles 5 and 30 of the ICC Statute that defined the crime; and contained in rules of international customary law and they are highlighted as: the intent to destroy, in whole or in part, a national, ethnical, racial or religious group. Genocide has been summarised as a typical crime based on the 'depersonalization of the victim. ${ }^{3}$ In other words, the victim of the crime is not really the object but rather the group to which the person belongs. Cassesse ${ }^{4}$ observed that those that commit the act of genocide against a victim only see the victim as a member of a protected group rather than as a human being.

This type of intent, according to scholars, ${ }^{5}$ amounts to 'aggravated criminal intent' (dolus specialis) ${ }^{6}$ and is usually required in addition to the criminal intent accompanying the underlying offence-

killing members of the group; causing serious bodily or mental harm to members of the group; deliberately inflicting on the group conditions of life calculated to bring about its physical destruction in whole or in part; imposing measures intended to prevent births within the group; forcibly transferring children of the group to another group.

What can be inferred from this provision is that other categories of intent such as gross negligence and recklessness, etc. can be excluded. The ICTR TC in Akayesu defined the 'aggravated criminal intent' in relation to the commission of genocide, as 'the specific intention required as a constitutive element of the crime which demands that the perpetrator clearly seeks to produce the act charged'.?

\footnotetext{
${ }^{1}$ The Convention on the Rights of the Child was adopted and opened for signature, ratification and accession by General Assembly resolution $44 / 25$ of 20 November 1989. It entered into force September 2, 1990, in accordance with article 49. It is available at, $<$ www2.ohchr.org/english/law/crc.htm $>$ accessed 17 November 2020. See also, The ILO Convention (No. 182) Concerning the Prohibition and Immediate Action for the Elimination of Worst Forms of Child Labour Convention, 1999, was adopted at the 87 ${ }^{\text {th }}$ Session on June 17, 1999 for the purpose of eliminating child labour and offer protection to children and young persons against labour exploitation. It came into force on November 19, 2000, but was ratified by Nigeria on October 2, available at, $<$ www.un.org/children/conflict/keydocuments/english/iloconvention1828.html > accessed 28 November 2020.

${ }^{2}$ See Akayesu, note 30, at para 509, Antonio Cassesse, note 28 at 134.

${ }^{3}$ Dragan Jovasevic, (2017) The Crime of Genocide in Theory and Practice of Criminal Law of Republic of Serbia Voj No Delo. 4, $224-235$

${ }^{4}$ Ibid. See also, Cassesse, note 28, p.137

${ }^{5}$ Aksar, Yusuf, (2009), "The Specific Intent (Dolus Specialis) Requirement of the Crime of Genocide: Confluence or Conflict between the Practice of Ad Hoc Tribunals and ICJ”, Uluslararası Illişkiler, Volume 6, No 23 p. 113-126.

${ }^{6}$ Paul Behrens, (2012) "Genocide and the Question of Motives" Journal of International Criminal Justice, vol. 10, Issue 3, 501-523

${ }^{7}$ Akayesu, note 30, para. 498, 517-522.
} 


\section{Proof of the subjective/mental element in genocide}

With regards to proof of mental element, the TC acknowledged that proving the mental element is extremely difficult, and near impossible to determine; and accordingly set out guidelines on how the mental element can be inferred in the absence of a confession. According to the court, intent of the accused person can be inferred from a certain number of presumptions of fact, particularly from 'all acts or utterances of the accused, or from the general context in which other culpable acts were perpetrated systematically against the same group'. This is regardless of whether such other acts were committed by the same perpetrator or by other perpetrators. This ruling was followed by the ICTR CT in several other cases including the case of The Prosecutor v. Clement Kayishema and Obed Ruzindana, Kajishema ${ }^{1}$ as well as Rutaganda. ${ }^{2}$ In Kayishema, the accused persons were charged with 24 counts as prefect of Kibuye with involvement as a superior in the massacres, which occurred in that area from April to June 1994. Ruzindana was charged with five counts for his role in the crimes committed in Bisesero between 9 April and 30 June 1994.On 21 May 1999, Trial Chamber II of the ICTR found both Accused guilty of crimes of genocide. Kayishema was found guilty of four counts of genocide and was sentenced to life imprisonment, while Ruzindana was found guilty of one count of genocide and was sentenced to 25 years of imprisonment. Both Accused appealed against their convictions and the sentence imposed on them. The appeal was based on several grounds including lack of equality of arms, defective indictment and inadequate proof against the accused. The Appeals Chamber, after examining the arguments, ruled that it was convinced that the Trial Chamber did not commit any error on a question of law or error of fact in the case. It therefore affirmed the judgment handed down by the Trial Chamber when convicting and sentencing the Accused.

\subsection{Elements required to be proved in a crime of genocide}

The requirement of 'unlawfulness' found in the ICC Statute ${ }^{3}$ or in other parts of international law, particularly international humanitarian law (IHL), ${ }^{4}$ is generally not specified in the elements of crimes. As used in the Elements of Crimes, ${ }^{5}$ the term 'perpetrator' ${ }^{6}$ is nonaligned to guilt or innocence. ${ }^{7}$ The elements, including appropriate mental elements, apply, mutatis mutandis, to all those whose criminal responsibility may fall under Articles $25^{8}$ and $28^{9}$ of the Rome Statute Further, a particular conduct may constitute one or more crimes. The elements of crimes are generally structured along the lines of certain principles:

- As the elements of crimes focus on the conduct, consequences and circumstances associated with each crime, they are generally listed in that order;

- Where required, a particular mental element is listed after the specific conduct, consequence or circumstance; and contextual circumstances are usually listed last

In relation to the last element listed for each crime: The term "in the context of" would include the initial acts in an emerging pattern;

- The term "manifest" is an objective qualification;

- Notwithstanding the normal requirement for a mental element provided for in article 30, and recognizing that knowledge of the circumstances will usually be addressed in proving genocidal intent, the appropriate requirement, if any, for a mental element regarding this circumstance will need to be decided by the Court on a case-by-case basis.

\subsection{Intent required prior to the commission of the act of genocide}

The need to establish the presence of intention prior to the commission of was succinctly established by the TC in Kayishema and Ruzindana" ${ }^{10}$ to the effect that "the mens rea must be formed prior to the commission of the

\footnotetext{
${ }^{1}$ Case No. ICTR-95-1-A

${ }^{2}$ Case No. ICTR-96-3-T

${ }^{3}$ The Rome Statute of International Criminal Court is the treaty, which established the International Criminal Court's jurisdiction, structure and functions. It was adopted on July 17, 1998 and entered into force on July 1, 2002 as the $60^{\text {th }}$ instrument of ratification was deposited with the Secretary General on April 11, 2002 when 10 countries simultaneously deposited their instruments of ratification. See also, http://www.un.org/law/icc/statute/romefra.htm: accessed 17 November 2020

${ }^{4}$ See for example, ICRC, Practice Relating to Rule 3. Definition of Combatants at $<$ http:ihl-databases.icrc.org $>$ 7June 2018. See also Articles 2 (f), 8 (2)(a)(iv)(vii), 31(1)(a)(b)(c), 33 and $85 b(1)$ of the Rome Statute.

${ }^{5}$ See Articles 9, 21 and 30 (1) of the Rome Statute. See also, Benjamin Whitaker, Revised and Updated Report on the Question of the Prevention and Punishment of the Crime of Genocide, UN Doc. E/CN.4/Sub.2/1985/6, paras. 30-35

${ }^{6}$ See the Preamble and Article 53 (2)(c)

${ }^{7}$ See Articles 65 and 66 of the Rome Statute; and Antonio Cassesse, note 28. See also, Raphael Lemkin, (1944), Axis Rule in Occupied Europe: Laws of Occupation, Analysis of Government, Proposals for Redress (Washington, Carnegie Endowment for International Peace, Division of International Law, 63, 90-94

${ }^{8}$ This Article establishes individual criminal responsibility and confer jurisdiction on the ICC to try individuals who commit offences within the jurisdiction of the court

${ }^{9}$ This Article makes commanders and other superiors criminally liable for crimes (within the court's jurisdiction) committed by persons or forces under their authority or control.

${ }^{10}$ (Trial Chamber), May 21, 1999, para. 91
} 
genocidal acts." even though the individual acts do not necessarily require premeditation in which case the only consideration would be that the act is "done in furtherance of the genocidal intent".

\subsubsection{Specific mental elements required}

Intent to destroy in whole or in part: "in part" relates to the intention to destroy a considerable number of individuals of the same group. ${ }^{2}$ In that regard, the International Law Commission (ILC) ${ }^{3}$ stated that 'the intention must be to destroy the group as such, meaning as a separate and distinct entity, and not merely some individuals because of their membership in particular group.' ${ }^{4}$ While agreeing with the ILC's statement, the TC observed that the "intention to destroy must target at least a substantial part of the group" even though the destruction sought need not be directed at every member of the targeted group. The main import of the provisions of both the Genocide Convention and the ICC Statute relating to destruction, is that the meaning of destroy only encompass acts or conducts that amount to physical or biological genocide. ${ }^{6}$ There are several forms of destruction one of which is sexual violence.

Generally, acts of sexual violence can form an integral part of the process of destruction of a group. This would be held to be the case where rapes resulted in physical and psychological destruction of women, their families and their communities belonging to a targeted group. In the case of Rwanda, sexual violence was held to be an integral part of the process of destruction, specifically targeting Tutsi women and specifically contributing to their destruction and to the destruction of the Tutsi group as a whole." 7

a) Killing members of the group- to establish this particular offence, the prosecutor must show that an accused intended to destroy the group as such, in whole or in part; that the perpetrator intentionally killed one or more members of the group, without the necessity of premeditation; and that such victim or victims belonged to the targeted ethnical, racial, national, or religious group. ${ }^{8}$ In the particular instance, intent is required.$^{9}$ Like in criminal law cases, causation of killing and other genocidal acts will be effected by an immediate proximate cause ion addition to the communication itself. Application of the principle of causation was considered in Akayesu where the Chamber found evidence of widespread killings throughout Rwanda sufficient to show both "killing" and "causing serious bodily harm to members of a group". The evidence includes the following:

- testimony regarding "heaps of bodies ... everywhere, on the roads, on the footpaths and in rivers and, particularly, the manner in which all these people had been killed",

- testimony stating that "many wounded persons in the hospital ... were all Tutsi and ... apparently, had sustained wounds inflicted with machetes to the face, the neck, and also to the ankle, at the Achilles' tendon, to prevent them from fleeing",

- testimony that the "troops of the Rwandan Armed Forces and of the Presidential Guard [were] going into houses in Kigali that had been previously identified in order to kill" and testimony of other murders elsewhere;

- "photographs of bodies in many churches" in various areas; and

- testimony regarding "identity cards strewn on the ground, all of which were marked 'Tutsi.", 10

b) Causing serious bodily or mental harm to members of the group

The TC in Akayesu, at paragraph 504 defined serious bodily or mental harm" as, inter alia, "acts of torture, be they bodily or mental, inhumane or degrading treatment, persecution." This meaning should however be "determined on a case-by-case basis, using a common sense approach" according to the TC in Kayishema and Ruzindana, ${ }^{11}$ noting that the meaning of "causing serious bodily harm" does not need serious interpretation as it is largely self-explanatory, and "could be construed to mean harm that seriously injures the health, causes disfigurement or causes any serious injury to the external, internal organs or senses. The harm caused here does not however need to be permanent or irremediable. By interpretation therefore, rape and sexual violence and threats during interrogation can qualify as stated in Akayesu, where the TC stated that rape and other acts of sexual violence constitute infliction of "serious bodily or mental harm" on members of the group; ${ }^{12}$ and that death threats during interrogation, alone or coupled with beatings, constitute infliction of "serious bodily or mental harm"

\footnotetext{
ibid

${ }^{2}$ see Kayishema at paras 96-97

${ }^{3}$ The ILC was established by the General Assembly in 1947 to undertake the mandate of the Assembly under Article 13(1)(a) of the UN Charter to "initiate studies and make recommendations for the purposes of ...encouraging the progressive development of international law...". See UN, International Law Commission-Office of Legal Affairs, <www.legal.un.org> accessed 5 September 2018

${ }^{4}$ See the TC in Kayishema at paras 96-97

${ }^{5}$ see Bagilishema, (Trial Chamber), June 7, 2001, para. 64

${ }^{6}$ See the TC in Akayesu, note 30. See also, Elisa Novic, (2015) Physical-Biological or Socio-cultural 'Destruction' in Genocide? Unveiling the Legal Underpinnings of Conflicting Interpretations Journal of Genocide Research 17, 63-82

${ }^{7}$ See also Kayishema and Ruzindana, (Trial Chamber), May 21, 1999, para. 95.

${ }^{8}$ Semanza, (Trial Chamber), May 15, 2003, para. 319

${ }^{9}$ See TC in Akayesu, note 30, para. 500-501. See also Article 2 (2) (a) of the Statute as well as Rutaganda at, para. 50

${ }^{10}$ See Akayesu, note 30 at, para. 114-116

${ }^{11}$ Kayeshima, para. 108-113

${ }^{12}$ See Akayesu, note 30 para. 706-707 and 731-734, 688. See also Kayishema and Ruzindana, (Trial Chamber), May 21, 1999, para. 108
} 
inflicted on members of the group. ${ }^{1}$ The specific element of intent to inflict serious mental harm is specifically required here.

c) Deliberately inflicting on the group conditions of life calculated to bring about its physical destruction in whole or in part

This phrase was interpreted in $A$ kayesu ${ }^{2}$ to mean "methods of destruction by which the perpetrator does not immediately kill the members of the group, but which, ultimately, seek their physical destruction." ${ }^{3}$ This includes, "inter alia, subjecting a group of people to a subsistence diet, systematic expulsion from homes and the reduction of essential medical services below minimum requirement."4 The deliberate act of inflicting on a group the conditions of life calculated to bring about its physical destruction in whole or in part" was also interpreted by the TC to include "circumstances which will lead to a slow death, for example, lack of proper housing, clothing, hygiene and medical care or excessive work or physical exertion" and "methods of destruction which do not immediately lead to the death of members of the group." ${ }^{5}$ Further, the TC held in Kayishema and Ruzindana, ${ }^{6}$ that although the Tutsi group in Kibuye were "deprived of food, water and adequate sanitary and medical facilities," "these deprivations were not the deliberate creation of conditions of life . . . intended to bring about their destruction" because these "deprivations . . . were a result of the persecution of the Tutsis, with the intent to exterminate them within a short period of time thereafter;" and that the times periods "were not of sufficient length or scale to bring about destruction of the group." 7

d) Imposing measures intended to prevent births within the group

One of the issues for consideration in Akayesu relates to the interpretation of this phrase. The TC held that imposing measures intended to prevent births within the group include: "sexual mutilation, the practice of sterilization, forced birth control, separation of the sexes and prohibition of marriages". A critical example is a patriarchal society ${ }^{9}$ where, during rape, a woman of the said group is deliberately impregnated by a man of another group, with the intent to have her give birth to a child who will consequently not belong to its mother's group. To that end, the TC noted that the measures might be mental as well as physical, referencing rape as a measure which can be intended to prevent births when the person raped refuses subsequently to procreate, in the same way that members of a group can be led, through threats or trauma, not to procreate. ${ }^{10}$

e) Forcibly transferring children of the group to another group

This phrase was again interpreted by the TC in Akayesu where it was observed that the objective of this phrase is two pronged-to sanction a direct act of forcible physical transfer; and to support acts of threats or trauma which would lead to the forcible transfer of children from one group to another. ${ }^{11}$

f) Complicity in the crime of genocide

Complicity in relation to the subjective element of genocide speaks to the issue of joint criminal enterprise ${ }^{12}$ as a principle of criminal law in which one or more persons perpetuate a criminal act with intent or knowledge. ${ }^{13}$ With regards to the element of complicity, the TC in Akayesu stated the true import of this concept and also laid the foundation for holding individuals accountable for conducts arising from mental element of complicity. ${ }^{14}$ According to the court,

...the intent or mental element of complicity implies ... that, at the moment he acted, the accomplice knew of the assistance he was providing in the commission of the principal offence. In other words, the accomplice must have acted knowingly." He is not required to "wish that the principal offence be committed." "[A]nyone who knowing of another's criminal purpose, voluntarily aids him or her in it, can be convicted of complicity even though he regretted the outcome of the offence. Thus, the mens rea ... required for complicity in genocide is knowledge of the genocidal plan.

This principally means that the perpetrator must have acted intentionally, knowing fully well that he was aiding, abetting or contributing to the offence of genocide "including all its material elements" as, stated in Semanza

\footnotetext{
Ibid

${ }^{2}$ Akayesu, note 30, para. 505-506

${ }^{3}$ Ibid

${ }^{4}$ Ibid

${ }^{5}$ Ibid

${ }^{6}$ Kayishema and Ruzindana, (Trial Chamber), May 21, 1999, para. 548

${ }^{7}$ Ibid

${ }^{8}$ Akayesu, note 30, para. 507-508

${ }^{9}$ in patriarchal societies, identity of the child is determined by that of the father.

${ }^{10}$ See also Kayishema and Ruzindana, (Trial Chamber), May 21, 1999, para. 117; Rutaganda, (Trial Chamber), December 6, 1999, para. 53;Musema, (Trial Chamber), January 27, 2000, para. 158.

${ }^{11}$ Akayesu note 30, para. 509: See also Kayishema and Ruzindana, (Trial Chamber), May 21, 1999, para. 118; Rutaganda, (Trial Chamber), December 6, 1999, para. 54; Musema, (Trial Chamber), January 27, 2000, para. 159.

${ }^{12}$ See Elies van Sliedregt, "Joint Criminal Enterprise as a Pathway to Convicting Individuals for Genocide" (2007) Journal of International Criminal Justice, 5 (1), 184-207

${ }^{13}$ Ibid

${ }^{14}$ Akayesu, note 30 para. 540-545
} 
supra. ${ }^{1}$ This raises the question of the nature of complicity in genocide. In that regard, unlike in the case of the main perpetrator of the crime of genocide, the element of dolis specialis is not required in the case of complicity. This was the position of the TC in $\mathrm{Akayesu}^{2}$ where it stated that:

[T] he intent of the accomplice is . . to knowingly aid or abet one or more persons to commit the crime of genocide." "Therefore . . . an accomplice to genocide need not necessarily possess the dolus specialis of genocide, namely the specific intent to destroy, in whole or in part, a national, ethnic, racial or religious group, as such." Thus, "an accused is liable as an accomplice to genocide if he knowingly aided or abetted or instigated one or more persons in the commission of genocide, while knowing that such a person or persons were committing genocide, even though the accused himself did not have the specific intent to destroy, in whole or in part, a national, ethnical, racial or religious group, as such.

\section{Elements not required to be proved}

\section{a) Specific plan not required, but is strong evidence of intent}

The rule that specific plan is not required was elucidated by the TC in Kayishema and Ruzindana ${ }^{3}$ where it was held that although a specific to destroy does not actually represent an element of genocide, it would appear that carrying out the act of genocide would be difficult in the absence of such a plan "or organisation". The ruling explains the irrelevance of a specific plan as bearing on the impossibility of the crime of genocide to be committed "without some or indirect involvement on the part of the State given the magnitude of this crime;" hence it becomes "unnecessary for an individual to have knowledge of all details of genocidal plan or policy." However, the existence of a genocidal plan would be strong evidence of the specific intent requirement for the crime of genocide. ${ }^{5}$

\section{b) Actual extermination of entire group not required}

The principle relating to the extermination of the group is such that it is not necessary for the entire group to be destroyed. But it is sufficient that once any one of the acts mentioned in Article 2(2)(a) through 2(2)(e) is committed with the specific intent to destroy 'in whole or in part' a national, ethnical, racial or religious group." Furthermore, it is not necessary to establish genocide throughout country. Except in the case of Rwanda, a person could be held accountable for the crime of genocide without necessarily having to establish that genocide had taken place throughout the country concerned."

\subsection{Where proof of intent is difficult}

Conceding that proving intent in genocidal cases could be difficult, or even impossible especially with regards to evidence gathering relating to confessional statements, the TC enumerates alternative means of establishing the presence of the subjective element in genocide. In the cases of Rutaganda, ${ }^{8}$ Musema, ${ }^{9}$ and Prosecutor $v$. Semanza, ${ }^{10}$ the TC noted that intent could be inferred: (a) from the material evidence submitted to the Chamber, including the evidence which demonstrates a consistent pattern of conduct by the Accused, (b) from the perpetrator's actions-deeds or words which should naturally be decipherable from "patterns of purposeful action"; 11 or (c) from the context of the act. However, this must be done on a case-by-case basis. Other factors from which intent can be inferred according to the TC in Akayesu includes the:

- scale of atrocities committed

- general nature of the atrocities committed in a region or a country;

- fact of deliberately and systematically targeting victims on account of their membership of a particular group, while excluding the members of other groups,

- general political doctrine which gave rise to the acts

- repetition of destructive and discriminatory acts; and or

- the perpetration of acts which violate, or which the perpetrators themselves consider to violate the very foundation of the group — acts which are not in themselves covered by the list . . but which are committed as part of the same pattern of conduct.

\footnotetext{
${ }^{1}$ See TC in Akaeyesu, 15 May 2003, para. 395

${ }^{2}$ Akayesu, note 30, para. 540-545:

${ }^{3}$ (Trial Chamber), May 21, 1999, para. 94, 276

${ }^{4}$ Ibid

${ }^{5}$ Ibid

${ }^{6}$ See Akayesu, note 30, at para. 731; and also Rutaganda, (Trial Chamber), December 6, 1999, para. 48-49

${ }^{7}$ Akayesu, Ibid

${ }^{8}$ (Trial Chamber), December 6, 1999, para. 61-63

${ }^{9}$ (Trial Chamber), January 27, 2000, para. 167

${ }^{10}$ Case No. ICTR-97-20 (Trial Chamber), May 15, 2003, para. 313 :

${ }^{11}$ See the case of Bagilishema, (Trial Chamber), June 7, 2001, para. 63:
} 


\section{Problems associated with genocide}

Beginning with the Genocide Convention through the Statutes of the International Military Tribunals, down to the ICC Statute, state signatories are under obligation to "prevent and to punish" genocide. But since the adoption of the definition of genocide, specifically under the Genocide Convention, it has been shrouded in controversy and condemnation. For example, it has been condemned for being too narrow as it excludes targeted political and social groups; and is limited to direct acts against people to the exclusion of the environment. ${ }^{1}$ Furthermore, it has been argued that proving intention beyond reasonable doubt ${ }^{2}$ in genocide cases is extremely difficult. ${ }^{3}$ Other difficulties associated with genocide include the fact that the concept is being devalued due to misuse, ${ }^{4}$ difficulty in measuring "in part". There is also the problem of hesitation by member states to single out other members or intervene, as was the case in Rwanda. ${ }^{5}$ Be that as it may, genocide, as agreed by some, ${ }^{6}$ is recognisable.

\section{Distinction between genocide and other crimes}

Genocide is clearly a serious crime, and so are other crimes within the ICC's jurisdiction. So the question is what sets genocide apart from the other crimes? For experts, ${ }^{7}$ the nature of genocide as a crime that embodies special intent (dolus specialis) is what makes it distinctive. ${ }^{8}$ The dolus specialis, according to Clark $^{9}$ is the specific intention required as a constitutive element of the crime. ${ }^{10}$ As pointed out above, it is that element that shows that the perpetrator clearly intend the outcome of the act for which he/she is charged. In the specific context of genocide, dolus specialis is "the intent to destroy, in whole or in part, a national, ethnical, racial or religious group". ${ }^{11}$ In that regards, the TC observed that "the offender is culpable only when he has committed one of the offences charged under Article 2(2) of the Genocide Convention (Article 6 of ICC Statute) with the clear intent to destroy, in whole or in part, a particular group". ${ }^{12}$ Accordingly, Akayesu was found culpable mainly because he knew or should have known that the act committed would destroy, in whole or in part, a group." 13 This was reechoed in the TC's Musema case. ${ }^{14}$ The TC stated in Rutaganda ${ }^{15}$ that one of the conditions upon which a person may be convicted of the offence of genocide is if the person committed one of the enumerated acts with "the specific intent to destroy, in whole or in part, a particular group."16

\section{Case Law on Elements of the Crime of Genocide}

Generally, genocide often occurs in societies where such groups become entangled or locked in identity-related conflicts. ${ }^{17}$ However, it is really not the differences in identity per se that generate tensions and conflicts. Rather, it is the real or perceived inequality associated with these differences in terms of access to power and resources, social services, development opportunities and the enjoyment of fundamental rights and freedoms. This principally speaks to issues around the need to ensure equality in the society, good governance and constructive management of diversity as a means of eliminating gross political and economic inequalities among groups; and for promoting a common sense of belonging on equal footing.

\section{Conclusion/Recommendations}

Ironically, the Convention on the Prevention and Punishment of the Crime of Genocide, 1948 otherwise known as the Genocide Convention does not provide any punishment for the crime of genocide or genocide related matters. ${ }^{18}$ Instead, the Convention empowered the Contracting. Parties to undertake to enact, in accordance with their

\footnotetext{
${ }^{1}$ See the TC in Akayesu case, note 30.

${ }^{2}$ Ibid. See also case of Bagilishema, (Trial Chamber), June 7, 2001, para. 63; and Kayishema case.

${ }^{3}$ Ibid

${ }^{4}$ See Human Rights Watch, Case Law of the International Criminal Tribunal for the Former Yugoslavia, $<$ www.hrw.org $>$ accessed 7 August 2018. See also UN, Guidance Note: when to refer to a situation as genocide, $<$ www.un.org $>$ accessed 3 September 2018

${ }^{5}$ BBC News, How the Genocide Happened (2011), <www.bbc.com> accessed 3 September 2018

${ }^{6}$ See for example, Alain Destexhe, Rwanda and Genocide in the $20^{\text {th }}$ Century ()

${ }^{7}$ See Melinda Rankin, "The Future of International Criminal Evidence in New Wars? The Evolution of the Commission for International Justice and Accountability" (2018) Journal of Genocide Research 20 (3), 392-411. See also, Antonio Cassesse, note 28. See also, Raphael Lemkin, (1944), Axis Rule in Occupied Europe: Laws of Occupation, Analysis of Government, Proposals for Redress (Washington, Carnegie Endowment for International Peace, Division of International Law, 63, 90-94

${ }^{8}$ Ibid.

9 Janine Natalya Clark, (2015) Elucidating the Dolus Specialis: An Analysis of ICTY Jurisprudence on Genocidal Intent Criminal Law Forum $26(3-4), 497-531$.

${ }^{10}$ Ibid

${ }^{11} \mathrm{Ibid}$

12 Akayesu, note 30, para. 498, 517-522.

${ }^{3}$ Ibid

14 Ibid, para. 164

${ }^{15}$ Ibid, para. 59

${ }^{16} \mathrm{Ibid}$

${ }^{17}$ For in-depth discussion on how identify-related conflict and inequality can cause war (and perhaps, genocide), see Gran Holmqvist, Inequality and Identity: causes of war? Discussion Paper 72, Nordiska Afrikainstitutet, Uppsala, 2012, pp. 8-15

${ }^{18}$ Appendix B, p. $324-328$, for the entire texts of the Convention on the Prevention and Punishment of the Crime of Genocide, 1948.
} 
respective Constitutions, the necessary legislation to give effect to the provisions of the Convention and, in particular, to provide effective penalties for persons guilty of genocide. ${ }^{1}$ But this lacuna is covered in Part 7 of Article 77 of the Rome Statute of the International Criminal Court. Unlike the Genocide Convention, the Rome Statute provides applicable penalties for a person convicted of genocide or genocide related matters. ${ }^{2}$

Persons committing acts of genocide must 'be punished whether they are constitutionally responsible rulers, public officials or private individuals' under Articles 25 and 27 of ICC Statute. Although the provisions in both the Genocide Convention and the ICC Statute enjoin parties to enact the necessary legislation 'to provide effective penalties for persons guilty of genocide, ${ }^{3}$ the most potent remedy would be to adopt preventive measures to forestall the occurrence of genocide. For example, states must address issues around guns and arms control. They can, in collaboration with the UN place embargo on countries and citizens involved in genocide activities. Prevention also involves enhanced national security measures and engaging in advocacy geared at discouraging the promotion of hate symbolisms-make them legally forbidden; and to make hate speeches culturally unacceptable. Additionally, the primary objective of criminalizing genocide by the Rome Statute is to ensure effective deterrence and to put an end to impunity. By its establishment, the message that has been sent to all and sundry, is that, the international community will no longer tolerate such monstrous acts without assigning responsibility and meting out punishment, be it to Heads of States, commanding officers or any individual who is desirous to commit this heinous crime of genocide.. Similarly, in this era of internal and international displacements and enhanced refugee crisis, real safe areas or refugee escape corridors should be established with heavily armed international protection. The most effective preventive measure is to address the root causes of disaffection within and outside the state. That means, good governance, equality and the promotion of and respect for human rights and the rule of law should tower above self-interest.

\section{REFERENCES}

Aksar, Yusuf, (2009), "The Specific Intent (Dolus Specialis) Requirement of the Crime of Genocide: Confluence or Conflict between the Practice of Ad Hoc Tribunals and ICJ", Uluslararası Ilişkiler, Volume 6, No 23 p. 113-126.

Antonio Cassesse, (2008) International Criminal Law (2 ${ }^{\text {nd }}$ edn.: Oxford University Press) p.133

Brill Online. The Genocide Convention: The Travaux Preparatoires (2 vols.) (2009), <http://brill.com $>$ accessed 6 August 2018.

Convention on the Prevention and Punishment of the Crime of Genocide' (1951) The American Journal of International Law, vol. 45, No. 1 Supplement: Official Documents (Jan., 1951) 7-13

Diane F Orentlicher, (1999) 'Genocide' in Roy Gutman, David Rieff and Anthony Dworkin (ed) Crimes of War: What the Public Should Know 2.0 (Reprint - edition W W Norton \& Co 191.

Elies van Sliedregt, "Joint Criminal Enterprise as a Pathway to Convicting Individuals for Genocide" (2007) Journal of International Criminal Justice, 5 (1), 184-207

Firew Kebede Tiba, (2007) "The Mengistu Genocide Trial in Ethoipia" Journal of International Criminal Justice 2(1), 513-528.

Gran Holmqvist, Inequality and Identity: causes of war? Discussion Paper 72, Nordiska Afrikainstitutet, Uppsala, 2012, pp. 8-15

Human Rights Watch, Case Law of the International Criminal Tribunal for the Former Yugoslavia, <www.hrw.org > accessed 7 August 2018.

Human Rights Watch, Genocide in Iraq, at <www.humanrightswatch.org> accessed 1 May 2018

Janine Natalya Clark, (2015) Elucidating the Dolus Specialis: An Analysis of ICTY Jurisprudence on Genocidal Intent Criminal Law Forum 26(3-4), 497-531.

John Richard Thackrah, (2008): The Routledge Companion to Military Conflict since 1945 Routledge Companion Series, Taylor \& Francis), 81-84

Kok-Thay Eng, Redefining Genocide; Carola Lingaas, (2015)

\footnotetext{
${ }^{1}$ Convention on the Prevention and Punishment of the Crime of Genocide 1948 Article 5

${ }^{2}$ The Rome State of the International Criminal Court provides that, the court may impose one of the

following penalties on a person convicted of a crime of genocide crimes against humanity war crimes and the crime of aggression: .

(1) (a) Imprisonment for a specified number of years, which may not exceed a maximum of 30 years; or.

(b). A term of life imprisonment when justified by the extreme gravity of !he crime and the

individual circumstances of the convicted person

(2) In addition to imprisonment the Court may order

(i,) A fine under the criteria provided for in the Rule of Procedure and Evidence;

(ii) A forfeiture of proceeds, property and assets derived directly or indirectly from the crime;

without prejudice to the rights of bonafida third parties

${ }^{3}$ See generally, 'Convention on the Prevention and Punishment of the Crime of Genocide' (1951) The American Journal of International Law, vol. 45, No. 1 Supplement: Official Documents (Jan., 1951) 7-13
} 
Lawrence R. Helfer and Ingrid B. Wuerth, (2016) "Customary International Law: An Instrument Choice Perspective" Michigan Journal of International Law, 37 (4), 563

Paul Behrens, (2012) "Genocide and the Question of Motives" Journal of International Criminal Justice, vol. 10, Issue 3, 501-523

Raphael Lemkin, (1944).Axis Rule in Occupied Europe: Laws of Occupation, Analysis of Government, Proposals for Redress (Washington, Carnegie Endowment for International Peace, Division of International Law, 